\title{
Photosensitive Organic-Inorganic Hybrid Materials for Room Temperature Gas Sensor Applications
}

\author{
Marina Rumyantseva ${ }^{1, *} \mathbb{C}$, Abulkosim Nasriddinov ${ }^{1}$, Svetlana Vladimirova ${ }^{1}$, \\ Sergey Tokarev ${ }^{1,2}$, Olga Fedorova ${ }^{1,2}$, Ivan Krylov ${ }^{3}$, Konstantin Drozdov ${ }^{3}$, \\ Alexander Baranchikov ${ }^{1,4}$ (iD) and Alexander Gaskov ${ }^{1}$ \\ 1 Chemistry Department, Moscow State University, 119991 Moscow, Russia; naf_1994@mail.ru (A.N.); \\ vladimirova.lagytina@gmail.com (S.V.); pergeybokarev@gmail.com (S.T.); fedorova@ineos.ac.ru (O.F.); \\ a.baranchikov@yandex.ru (A.B.); gaskov@inorg.chem.msu.ru (A.G.) \\ 2 Nesmeyanov Institute of Organoelement Compounds of the Russian Academy of Sciences, \\ 119991 Moscow, Russia \\ 3 Physics Department, Moscow State University, 119991 Moscow, Russia; ivan.phys@gmail.com (I.K); \\ kadrozdov@gmail.com (K.D.) \\ 4 Kurnakov Institute of General and Inorganic Chemistry of the Russian Academy of Sciences, \\ 119991 Moscow, Russia \\ * Correspondence: roum@inorg.chem.msu.ru; Tel.: +7-495-939-5471
}

Received: 24 July 2018; Accepted: 28 August 2018; Published: 29 August 2018

\begin{abstract}
In this work, the hybrids based on nanocrystalline $\mathrm{SnO}_{2}$ or $\mathrm{In}_{2} \mathrm{O}_{3}$ semiconductor matrixes and heterocyclic $\mathrm{Ru}$ (II) complex are studied as materials for gas sensors operating at room temperature under photoactivation with visible light. Nanocrystalline semiconductor oxides are obtained by chemical precipitation with subsequent thermal annealing and characterized by $\mathrm{XRD}, \mathrm{SEM}$ and single-point BET methods. The heterocyclic $\mathrm{Ru}(\mathrm{II})$ complex is synthesized for the first time and investigated by ${ }^{1} \mathrm{H}$ NMR, ${ }^{13} \mathrm{C}$ NMR APT, MALDI-MS analysis, and UV-Vis spectroscopy. The HOMO and LUMO energies of the Ru(II) complex are calculated from cyclic voltammetry data. The hybrid materials are characterized by TGA-MS analysis and EDX mapping. The optical properties of hybrids are studied by UV-Vis spectroscopy in the diffuse reflection mode. The investigation of spectral dependencies of photoconductivity of hybrid samples demonstrates that the role of organic dye consists in shifting the photosensitivity range towards longer wavelengths. Sensor measurements demonstrate that hybrid materials are able to detect $\mathrm{NO}_{2}$ in the concentration range of $0.25-2 \mathrm{ppm}$ without the use of thermal heating under periodic illumination with even low-energy long-wavelength (red) light.
\end{abstract}

Keywords: organic-inorganic hybrid materials; tin dioxide; indium oxide; $\mathrm{Ru}(\mathrm{II})$ complex; $\mathrm{NO}_{2}$; semiconductor gas sensor; visible light activation

\section{Introduction}

The World Health Organization (WHO) has included inorganic gases, i.e., carbon monoxide (CO), nitrogen dioxide $\left(\mathrm{NO}_{2}\right)$, sulphur dioxide $\left(\mathrm{SO}_{2}\right)$, and ozone $\left(\mathrm{O}_{3}\right)$, in the list of gases that have indoor sources, which are known in respect of their hazardousness to health and are often found indoors in concentrations of health concern [1]. Semiconductor gas sensors are promising for indoor and outdoor air monitoring because of their extremely high sensitivity, stability and miniaturization capability. The combination of gas sensors with information networks (including portable devices and mobile phones [2]) allows reporting a leakage and/or exceeding the maximum allowable concentration of hazardous gases upon short- or long-term exposures. However, the operating temperatures necessary 
for detection of the gases listed above are quite high: $250-350{ }^{\circ} \mathrm{C}(\mathrm{CO}), 150-200{ }^{\circ} \mathrm{C}\left(\mathrm{NO}_{2}\right), 300-350{ }^{\circ} \mathrm{C}$ $\left(\mathrm{SO}_{2}\right), 200-300{ }^{\circ} \mathrm{C}\left(\mathrm{O}_{3}\right)$ [3-5]. The need for heating significantly increases power consumption, which is the main restriction for coupling gas sensors with portable and mobile devices. Thus, the design of new materials that show gas sensitivity under conditions of minimal thermal heating is one of the key directions in developing the technology of gas sensors and multisensor systems.

When using semiconductor gas sensors, the formation of sensor response towards oxidizing gases $\left(\mathrm{NO}_{2}, \mathrm{O}_{3}\right)$ occurs due to the adsorption of electron acceptor particles on the surface of semiconductors, which is accompanied by the localization of electrons on the adsorbed species. The recovery of the initial state of the surface and the electrophysical properties of the sensitive material occurs due to desorption of the molecules of the detected gas, which requires an increase in temperature. The use of photoactivation, instead of thermal heating, is an alternative, promising for lowering the power consumption of the sensor. The majority of articles that deal with sensor properties of semiconductor materials under illumination are devoted to studies carried out under UV light [6-26]. The light sources of the visible range $(\lambda=400-800 \mathrm{~nm}$ ) have a lower energy consumption compared to the sources of UV radiation. In addition, the visible range corresponds to the maximum intensity of solar radiation, which can be additionally used as a source of illumination. However, bulk wide-gap metal oxides are transparent in the visible range of the spectrum. Based on the published data [27-40] for shifting the wavelength range of optical sensitivity of transparent conductive oxides towards longer wavelengths, it is necessary to create defects in the semiconductor matrix [27-32] or to introduce sensitizers, providing absorption in the visible region. Therefore, semiconductors of $A^{2} B^{6}$ group $(C d S$, $E_{g}=2.4 \mathrm{eV}$; CdSe, $E_{g}=1.7 \mathrm{eV}$ ) and $\mathrm{A}^{3} \mathrm{~B}^{5}$ group $\left(\mathrm{InP}, E_{g}=1.35 \mathrm{eV}\right)[28,33-36]$, as well as organic dyes (i.e., macrocyclic and heterocyclic complexes of transition metals [38-40]), are investigated.

Polypyridine $\mathrm{Ru}(\mathrm{II})$ complexes are intensively studied as photosensitizers for photochemical and photoelectrochemical conversion of solar energy [41]. The oxidation-reduction properties of the triplet metal-to-ligand charge transfer state in $\mathrm{Ru}\left(\mathrm{bpyy}_{3}\right)^{2+}$ and its relatively long lifetime are the main reasons for its successful use in photovoltaic converters [42-44], and devices for water photolysis [43-45]. The possibility to adjust the optical and electrochemical properties by a reasonable choice of heterocyclic chelating ligands and relatively easy synthesis determines the suitability of using $\mathrm{Ru}$ (II) mononuclear complexes. The lowest unoccupied molecular orbitals (LUMOs) of diazine ligands with two-ring $\mathrm{N}$-heteroatoms are lower in energy, compared with substituted bipyridines [46,47]. The possibilities of use of Ru (II) complexes with 3,3-bipyridazine [48], 2,2-bipyrazine [49], 2,2-bipyrimidine [50] and 4,4-bipyrimidine [51-53] ligands in devices for converting solar energy are discussed.

In the present research, the hybrids based on nanocrystalline $\mathrm{SnO}_{2}$ or $\operatorname{In}_{2} \mathrm{O}_{3}$ semiconductor matrixes and $\mathrm{Ru}(\mathrm{II})$ complex with $1 H$-imidazo[4,5-f][1,10]phenanthroline derivative were studied as materials for gas sensors operating at room temperature under photoactivation with visible light. Investigation of the interaction of hybrids with $\mathrm{NO}_{2}$ at room temperature under blue $\left(\lambda_{\max }=470 \mathrm{~nm}\right)$, green $\left(\lambda_{\max }=535 \mathrm{~nm}\right)$ and red $\left(\lambda_{\max }=630 \mathrm{~nm}\right)$ light illumination has shown that the use of sensitization with organic dyes is an effective way to significantly improve the room-temperature gas sensor properties of semiconductor oxide materials.

\section{Results and Discussion}

\subsection{Characteristics of Nanocrystalline Semiconductor Oxides}

The diffraction pattern of $\mathrm{SnO}_{2}$ corresponds to the phase with the tetragonal cassiterite structure with a crystallite size of 3-4 nm, and the diffraction pattern of the $\operatorname{In}_{2} \mathrm{O}_{3}$ corresponds to the phase with a cubic structure of bixbyite with a crystallite size of 7-8 $\mathrm{nm}$ (Figure 1). The particle size distributions for $\mathrm{SnO}_{2}$ and $\mathrm{In}_{2} \mathrm{O}_{3}$ samples obtained under similar conditions were investigated by transmission electron microscopy (TEM) in our previous work [28]. The particle size determined by the TEM method was $4 \pm 1 \mathrm{~nm}$ for $\mathrm{SnO}_{2}$ and $7 \pm 2 \mathrm{~nm}$ for $\mathrm{In}_{2} \mathrm{O}_{3}$. The specific surface area determined by the single-point Brunauer-Emmett-Teller (BET) method was $110 \pm 5 \mathrm{~m}^{2} / \mathrm{g}$ for $\mathrm{SnO}_{2}$ and $60 \pm 5 \mathrm{~m}^{2} / \mathrm{g}$ for 
$\mathrm{In}_{2} \mathrm{O}_{3}$. Figure 2 presents the micrographs of $\mathrm{In}_{2} \mathrm{O}_{3}(\mathrm{a})$ and $\mathrm{SnO}_{2}(\mathrm{~b})$ thick films formed on the dielectric substrate of the measured chip. Thick films were porous, consisting of agglomerated and sintered grains. The size of agglomerates was about $100 \mathrm{~nm}$.
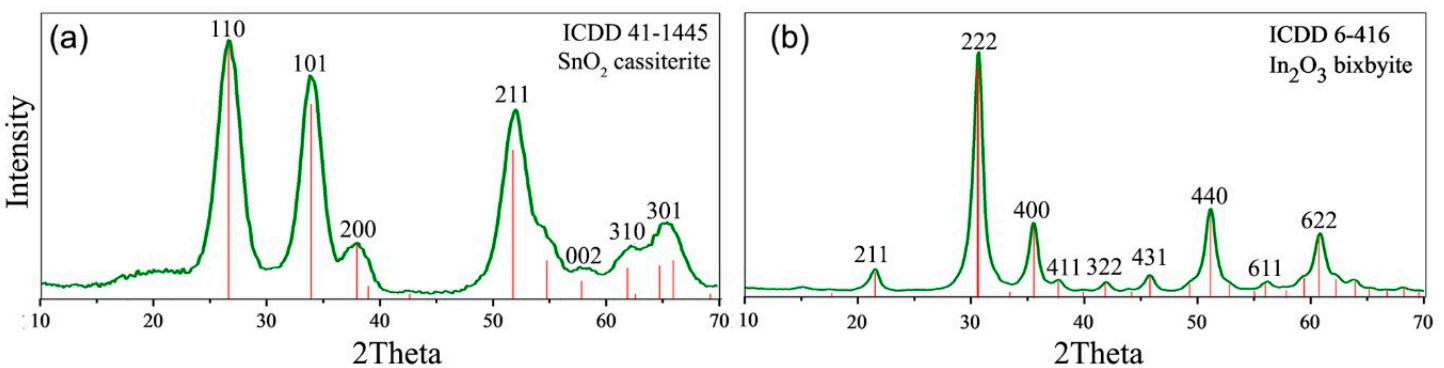

Figure 1. XRD patterns of $\mathrm{SnO}_{2}(\mathbf{a})$ and $\mathrm{In}_{2} \mathrm{O}_{3}(\mathbf{b})$ samples.
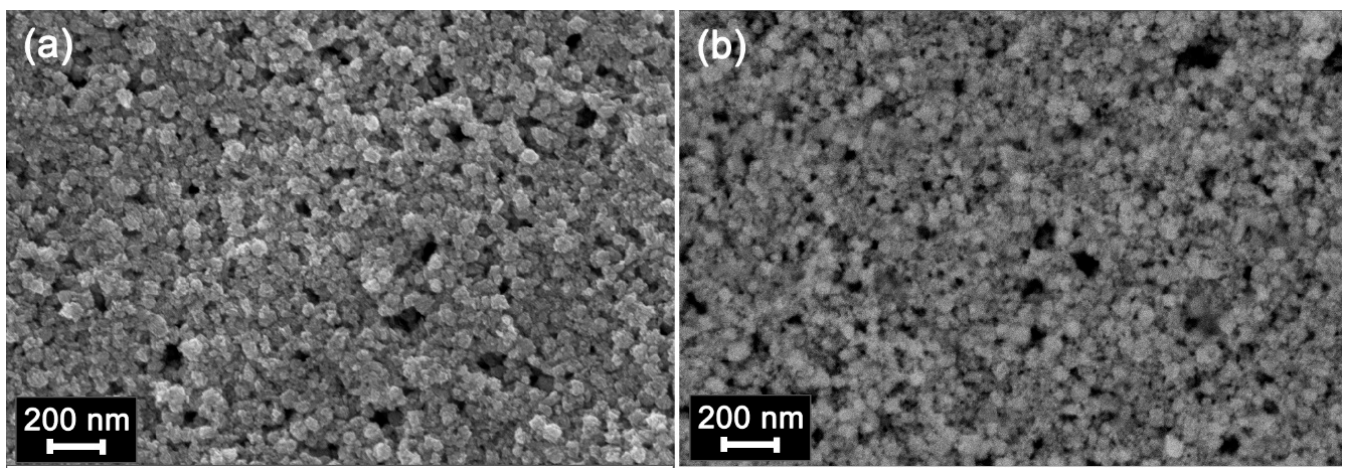

Figure 2. SEM images of $\mathrm{In}_{2} \mathrm{O}_{3}(\mathbf{a})$ and $\mathrm{SnO}_{2}$ (b) thick films deposited on functional substrates (see Materials and Methods) and sintered at $300{ }^{\circ} \mathrm{C}$.

\subsection{Characteristics of Ru(II) Heterocyclic Complex}

The structure and absorption spectrum of heteroleptic $\mathrm{Ru}(\mathrm{II})$ complex bis(2,2'-bipyridine- $\left.\mathrm{k}^{2} N^{1}, N^{1 \prime}\right)\left[2-\left(2,2^{\prime}\right.\right.$-bithiophen-5-yl)-1H-imidazo[4,5-f][1,10]phenanthroline- $\left.\mathrm{k}^{2} N^{7}, N^{8}\right)$ ruthenium $\left(2^{+}\right)$dichloride (Ru-TT) are presented in Figure 3. The absorption bands in the UV range of Ru-TT $\left(5 \times 10^{-5} \mathrm{M}\right.$ solution in methanol) spectrum are due to ligand-centered (LC) $\pi-\pi^{*}$ transitions. The $1 H$-imidazo-phenantroline ( $\mathrm{ImPh}$ ) and pyridine $\pi-\pi^{*}$ transitions overlap in the $287 \mathrm{~nm}$ range [54,55]. Additionally, the $\pi-\pi^{*}$ transitions of substituted $\mathrm{ImPh}$ residues are in the region of 320-380 $\mathrm{nm}$. In the visible region, Ru-TT complex displays the metal-to-ligand charge transfer $\left({ }^{1} \mathrm{MLCT}\right)$ transition band $(460 \mathrm{~nm})$ associated with a $\mathrm{d}(\mathrm{Ru})-\pi^{*}$ (substituted $\mathrm{ImPh}$ ligand) transition.

The voltammogram of Ru-TT complex exhibits three irreversible oxidation waves $\left(E_{1 / 2(o x)}\right)$ and three reduction waves $\left(E_{1 / 2(\mathrm{red})}\right)$ (Table 1$)$. All observed electron reductions are ligand centered. The first two one-electron reductions of the complex are reversible, and the corresponding potentials are assigned to the reduction of the $\mathrm{ImPh}$ ligand as it is more easily reduced than 2,2-bipyridine. The third reduction potential at $-1.96 \mathrm{~V}$ is very close to that obtained for the $\left[\mathrm{Ru}(\mathrm{bpy})_{3}\right]^{2+}$ complex and is assigned to the reduction of the bpy ligand [56]. The oxidation potentials range from $+1.23 \mathrm{~V}$ to $+1.52 \mathrm{~V}$ for the heteroleptic complex and are attributed to the one-electron oxidation of the metal-centered highest-occupied molecular orbital (HOMO) (Table 1). The potential data for the metal-centered oxidation $\mathrm{Ru}(\mathrm{II} / \mathrm{III})$, oxidation of ligands or chloride-anion should be close to each other, which makes interpretation of the obtained oxidation potential data difficult. 


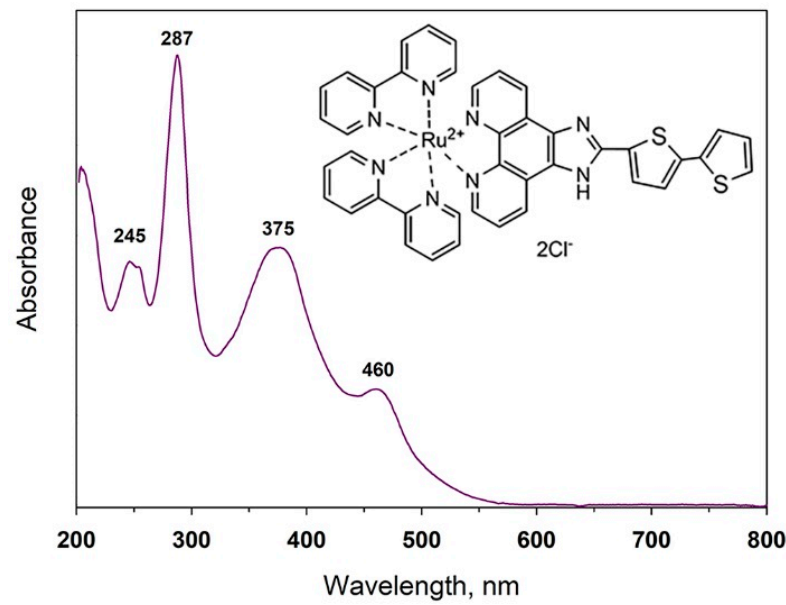

Figure 3. Structure and optical absorption spectrum of Ru-TT complex in a $5 \times 10^{-5} \mathrm{M}$ methanol solution.

Table 1. Electrochemical data and calculated values of HOMO and LUMO of Ru-TT complex.

\begin{tabular}{cccc}
\hline$E_{1 / 2(\text { red) }}, \mathrm{V}$ & $E_{\mathbf{1 / 2}(\mathrm{ox})}, \mathrm{V}$ & $E_{\text {HOMO, }}, \mathrm{eV}$ & $E_{\mathrm{LUMO}}, \mathrm{eV}$ \\
\hline$-1.27 /-1.21$ & 1.23 & & \\
$-1.48 /-1.41$ & 1.42 & -6.15 & -3.46 \\
$-1.96 /-1.84$ & 1.52 & & \\
\hline
\end{tabular}

\subsection{Characteristics of Hybrid Samples}

The impregnation of $\mathrm{SnO}_{2}$ and $\mathrm{In}_{2} \mathrm{O}_{3}$ thick films with the $\mathrm{Ru}-\mathrm{TT}$ methanolic solution resulted in appearance of bright red-orange coloration (Figure 4a,b). According to the results of energy-dispersive X-ray spectroscopy (EDX) mapping effectuated on sensitized thick films, the molecules of the heterocyclic Ru-TT complex were distributed unevenly on the surface of semiconductor oxides, filling regions with a diameter of 30-70 $\mu \mathrm{m}$ (Figure 4c,d). The average content of ruthenium in $\mathrm{SnO}_{2}$ and $\mathrm{In}_{2} \mathrm{O}_{3}$ thick films was $\frac{[R u]}{[R u]+[M]}=1-2$ at $\%(\mathrm{M}=\mathrm{Sn}, \mathrm{In})$ (Table 2).
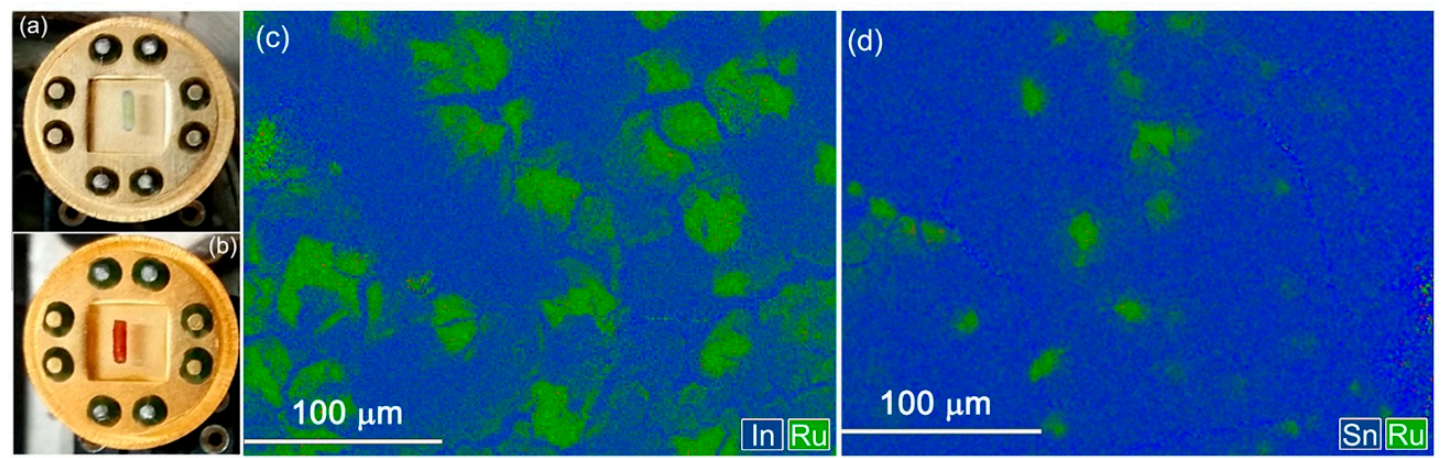

Figure 4. Optical images of $\mathrm{SnO}_{2}$ thick films deposited on functional substrates (see Materials and Methods) before (a) and after (b) sensitization with the Ru-TT complex. EDX maps of element distribution on the surface of $\operatorname{In}_{2} \mathrm{O}_{3} \mathrm{Ru}-\mathrm{TT}$ (c) and $\mathrm{SnO}_{2}$ Ru-TT (d) thick films. 
Table 2. Microstructure characteristics, composition and photoresponse of investigated samples.

\begin{tabular}{|c|c|c|c|c|c|}
\hline Sample & $\mathrm{d}_{\mathrm{XRD}}{ }^{\mathrm{a}}, \mathrm{nm}$ & $\mathrm{d}_{\text {TEM }}{ }^{b}, \mathrm{~nm}$ & $S_{\text {surf }}{ }^{c}, m^{2} / g$ & $\frac{[R \boldsymbol{u}]}{[\boldsymbol{R} u]+[\boldsymbol{M}]^{d}}, a t . \%$ & $\begin{array}{c}S_{P h} e \text { in Pure Air } \\
(\lambda=470 \mathrm{~nm})\end{array}$ \\
\hline $\begin{array}{c}\mathrm{SnO}_{2} \\
\mathrm{SnO}_{2} \mathrm{Ru}-\mathrm{TT}\end{array}$ & $4 \pm 1$ & $4 \pm 1$ & $110 \pm 5$ & $\begin{array}{c}- \\
1.4 \pm 0.1\end{array}$ & $\begin{array}{l}1.00 \\
2.72\end{array}$ \\
\hline $\begin{array}{c}\mathrm{In}_{2} \mathrm{O}_{3} \\
\mathrm{In}_{2} \mathrm{O}_{3} \mathrm{Ru}-\mathrm{TT}\end{array}$ & $7 \pm 1$ & $7 \pm 2$ & $60 \pm 5$ & $\begin{array}{c}- \\
2.1 \pm 0.2\end{array}$ & $\begin{array}{l}1.30 \\
3.15\end{array}$ \\
\hline
\end{tabular}

${ }^{a} \mathrm{MO}_{\mathrm{x}}$ crystallite size, estimated from XRD data; ${ }^{\mathrm{b}} \mathrm{MO}_{\mathrm{x}}$ particle size (TEM); ${ }^{\mathrm{c}} \mathrm{MO}_{\mathrm{x}}$ specific surface area; ${ }^{\mathrm{d}}$ obtained by EDX on thick films: $\mathrm{M}=\mathrm{Sn}$ for the $\mathrm{SnO}_{2} \mathrm{Ru}$-TT sample; $\mathrm{M}=\mathrm{In}$ for the $\mathrm{In}_{2} \mathrm{O}_{3}$ Ru-TT sample; ${ }^{\mathrm{e}}$ Effective photoresponse.

The range of thermal stability of semiconductor oxides sensitized with the Ru-TT complex was determined by thermogravimetric analysis combined with mass spectral analysis of gaseous products (TG-MS). Figure 5 shows the MS signals of $\mathrm{CO}_{2}(\mathrm{~m} / \mathrm{z}=12, \mathrm{~m} / \mathrm{z}=44), \mathrm{NO}(\mathrm{m} / \mathrm{z}=30)$, and $\mathrm{H}_{2} \mathrm{O}$ $(\mathrm{m} / \mathrm{z}=18)$, corresponding to the fragmentation products of the $\mathrm{SnO}_{2} \mathrm{Ru}-\mathrm{TT}$ sample. Analysis of thermograms and mass spectra showed that, in the temperature range $35-150{ }^{\circ} \mathrm{C}$, the sample was dried with removal of adsorbed water. The decomposition of Ru-TT complex was exothermic and set on above $200{ }^{\circ} \mathrm{C}$, as evidenced by a pronounced peak on the curve of thermal effects and $\mathrm{CO}_{2}$ emission. Thus, under conditions of sensor measurements at room temperature, the sensitizer was thermally stable.
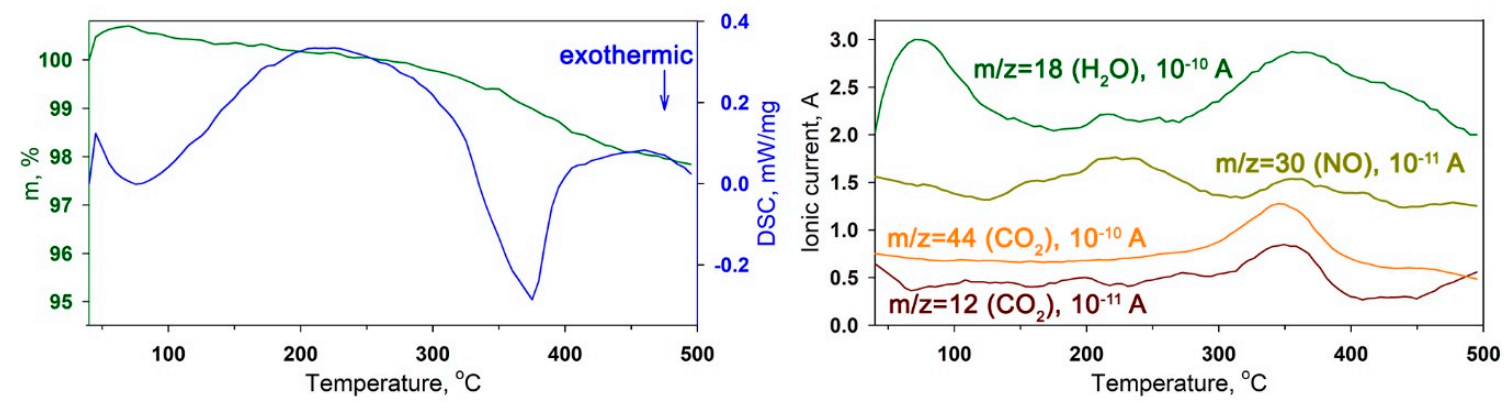

Figure 5. TG, DSC and MS curves of the $\mathrm{SnO}_{2} \mathrm{Ru}-\mathrm{TT}$ hybrid sample.

A comparison of optical and photoelectrical properties of pure semiconductor matrixes, $\mathrm{Ru}$-TT complex and hybrid materials is shown in Figure 6. The greatest influence of Ru-TT complex on the optical properties of composites appeared in visible spectral range. In both hybrids, the intensive absorption band was observed at $\lambda_{\max }=472 \mathrm{~nm}$, due to the presence of organic sensitizer. As compared with the spectrum of Ru-TT complex, the maximum of the absorption edge was shifted to the long-wavelength region by about $10 \mathrm{~nm}$. Even though the constituent components of hybrids do not have absorption bands at $\lambda>500 \mathrm{~nm}$, the spectra of sensitized materials exhibited a broad shoulder in the long-wavelength region around $510-620 \mathrm{~nm}$. This can be caused by the aggregation of Ru-TT molecules on the surface of the semiconductor oxides [57].

The photoconductivity of hybrid samples (Figure 6) in the visible spectral region increased from $600 \mathrm{~nm}$ and reached a maximum value at $480-500 \mathrm{~nm}$. The shape of the spectral dependences of the hybrid's photoconductivity agrees with their optical absorption spectra. This allows us to state that the photoexcitation of organic dye is accompanied by the injection of electrons from the Ru-TT complex into $\mathrm{In}_{2} \mathrm{O}_{3}$ and $\mathrm{SnO}_{2}$ semiconductor matrixes. 

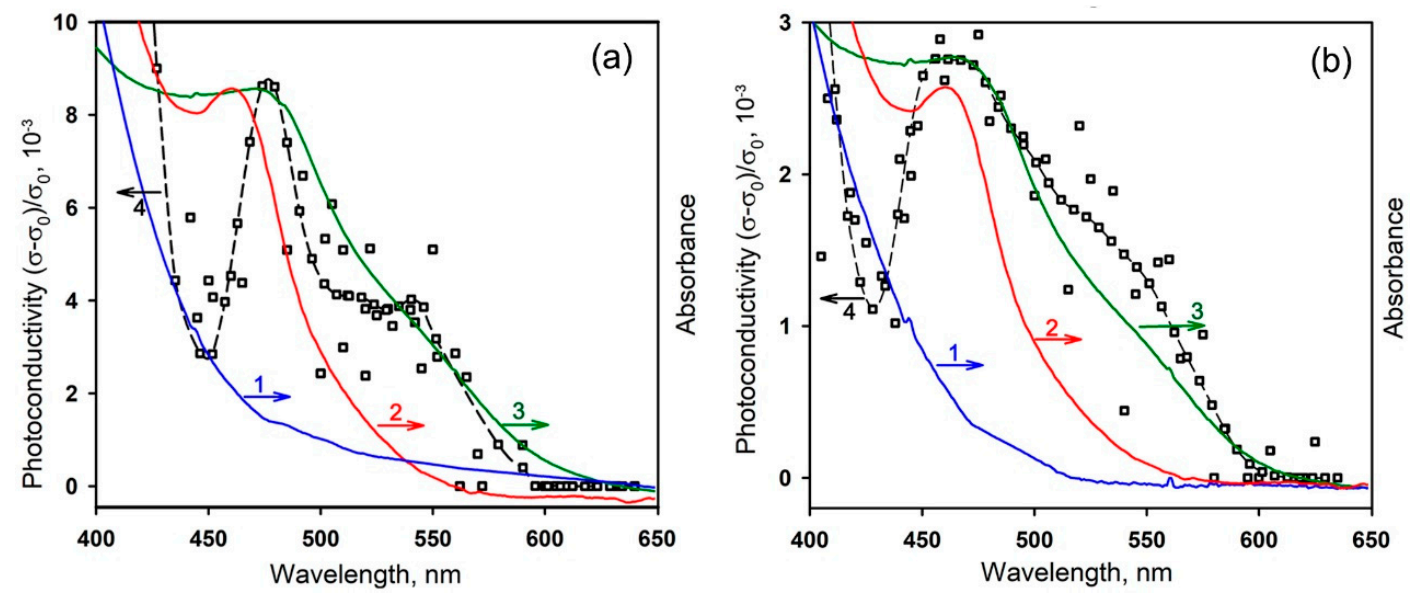

Figure 6. Absorption spectra of the pure semiconductor oxide (1), Ru-TT complex (2), hybrid sample (3) and spectral dependences of photoconductivity (4) of $\mathrm{In}_{2} \mathrm{O}_{3} \mathrm{Ru}-\mathrm{TT}$ (a) and $\mathrm{SnO}_{2} \mathrm{Ru}-\mathrm{TT}$ (b).

\subsection{Gas Sensor Properties}

Our previous investigations of gas sensor properties of nanocomposites, consisting of a semiconductor oxide matrix and photosensitizers-semiconductor quantum dots, performed under constant and periodic illumination, demonstrated that the latter option is preferable because of long recovery time constants (more than $1 \mathrm{~h}$ ) necessary to return to the equilibrium resistance under constant illumination [35,58]. In this procedure, the illumination of the sensor element is carried out in a pulsed mode with a short period ( $2 \mathrm{~min}$ "on"-2 min "off"). If the illumination cycle is repeated, the change in the sensor resistance in each of the following cycles comes very close to the previous one. This steady state can be characterized by the minimum resistance $R_{\text {light }}$, which is achieved during the sensor illumination, and the maximum $R_{\text {dark }}$, which is achieved in the dark period (Figure 7). From these values, the effective photoresponse can be calculated as:

$$
S_{P h}=\frac{R_{\text {dark }}}{R_{\text {light }}}
$$

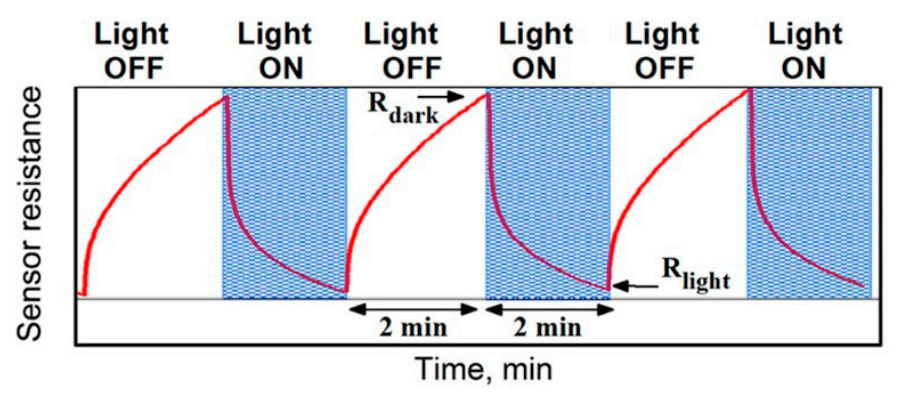

Figure 7. Scheme of resistance change of n-type semiconductor under periodic illumination.

In pure air, the decrease of the material resistance under illumination and its increase upon turning the light off are determined by the dynamic equilibrium between adsorption and photodesorption of oxygen:

$$
\begin{aligned}
& O_{2(g a s)}+e^{-} \leftrightarrow O_{2(a d s)^{-}}^{-} \\
& O_{2(a d s)}^{-}+h^{+} \leftrightarrow O_{2(g a s)},
\end{aligned}
$$


where $O_{2(g a s)}$ is an oxygen molecule in the gas phase, $\mathrm{O}_{2(\text { ads })}^{-}$is the molecular form of chemisorbed oxygen, $e^{-}$is an electron, which can be localized on an electrophilic oxygen molecule, and $h^{+}$is a photogenerated hole. For bulk wide-gap semiconductor oxides, the photodesorption of oxygen occurs only under UV illumination. However, for nanocrystalline materials, this process becomes possible even under visible light due to the presence of sub-band surface states [59]. In this case, the consequential mechanism for the generation of holes is realized: (I) under visible light, the electrons localized at acceptor levels in the forbidden band of semiconductor are transferred to the conduction band, (II) thermal transitions of electrons from the valence band to empty acceptor levels result in hole generation (Figure 8a). This mechanism is much weaker than the band gap mechanism realized under UV light, and the corresponding threshold energy is $E_{g}-E_{a}$, where $E_{a}$ is the ionization energy of the acceptor [60]. The small value of the visible light photoresponse observed for nanocrystalline oxides $\mathrm{SnO}_{2}$ and $\mathrm{In}_{2} \mathrm{O}_{3}$ in air (Table 2) confirms the realization of this mechanism.

(a)

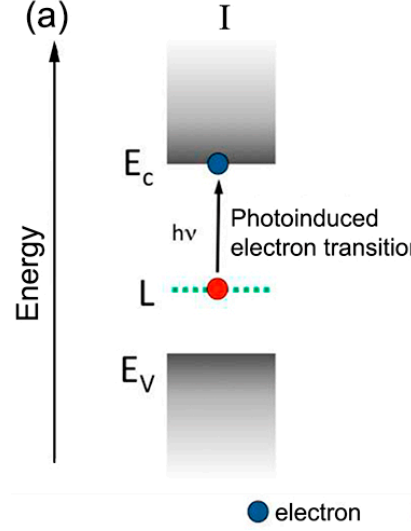

II

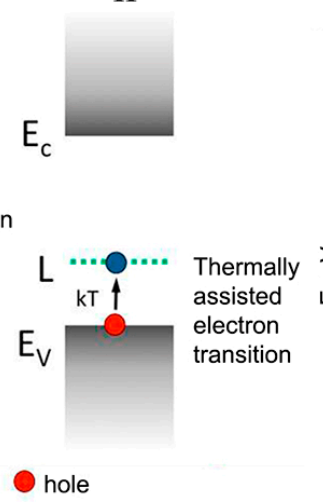

(b)

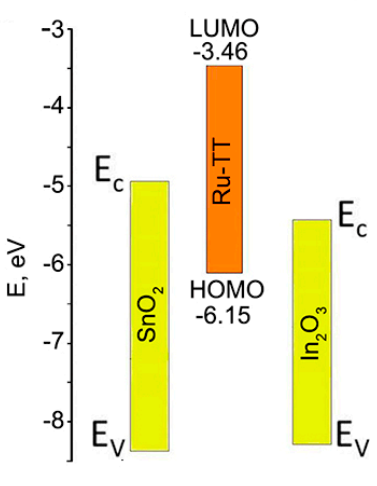

Figure 8. (a) Scheme of the consequential mechanism for the generation of holes in pure nanocrystalline oxides under visible light illumination. $E_{v}$-valence band, $E_{\mathcal{C}}$-conduction band, $L$-acceptor level. (b) Scheme of the mutual arrangement of the energy levels for bulk $\operatorname{In}_{2} \mathrm{O}_{3}, \mathrm{SnO}_{2}$, and $\mathrm{HOMO}$ and LUMO of the Ru-TT complex.

The introduction of an organic sensitizer leads to an increase in the photoresponse in pure air of both tin oxide and indium oxide (Table 2). Figure $8 \mathrm{~b}$ illustrates the mutual arrangement of the energy levels for bulk $\mathrm{In}_{2} \mathrm{O}_{3}, \mathrm{SnO}_{2}$, and HOMO and LUMO of the Ru-TT complex. The positions of valence $\left(E_{V}\right)$ and conduction $\left(E_{C}\right)$ bands for bulk $\mathrm{SnO}_{2}$ and $\mathrm{In}_{2} \mathrm{O}_{3}$ were taken from ref. [61]. When hybrids are illuminated with visible light, the electrons of Ru-TT complex are excited from the HOMO to LUMO level, which is above the conduction band minimum of semiconductor matrix. These photoexcited electrons can be transferred to the conduction bands of $\mathrm{SnO}_{2}$ and $\operatorname{In}_{2} \mathrm{O}_{3}$, which results in an increase in their conductivity. Therefore, under illumination, the HOMO level of organic complex becomes electron-depleted. To regenerate the dye, it is necessary to ensure the transfer of the electron from any reducing particle to its HOMO. This can be done by the electrons localized by chemisorbed oxygen on the surface of the semiconductor oxide. Therefore, the oxygen molecule passes back into a physically adsorbed neutral form, which can be easily removed from the surface.

Since nitrogen dioxide (electron affinity $2.27 \mathrm{eV}$ [62]) is a stronger electron acceptor than oxygen (electron affinity $0.44 \mathrm{eV}$ [63]), the adsorption equilibria:

$$
\begin{gathered}
\mathrm{NO}_{2(\text { gas })}+e^{-} \leftrightarrow \mathrm{NO}_{2(a d s)}^{-} \\
\mathrm{NO}_{2(\text { gas })}+\mathrm{O}_{2(\text { ads })}^{-} \leftrightarrow \mathrm{NO}_{2(\text { ads })}^{-}+\mathrm{O}_{2(\text { gas })}
\end{gathered}
$$

are more strongly shifted towards the chemisorbed form of $\mathrm{NO}_{2}$ as compared to the chemisorbed form of $\mathrm{O}_{2}$. 
It has been shown in $[12,35,64]$ that, under dark conditions, the adsorption of $\mathrm{NO}_{2}$ on the surface of semiconductor oxides proceeds irreversibly at room temperature. Thus, when $\mathrm{NO}_{2}$ is removed from the atmosphere, its desorption from the surface of the semiconductor oxide does not occur. However, this desorption process is a prerequisite for restoring the initial state of the surface and the electrical properties of the sensitive material, providing the formation of a reproducible sensor signal. In our previous works $[28,35,58]$, it was demonstrated that the role of illumination consists in the photogeneration of holes that ensure (as in the case of oxygen) the conversion of chemisorbed particles into physically sorbed ones, which can be easily desorbed from the surface of the semiconductor oxide even at room temperature due to thermal fluctuations:

$$
\mathrm{NO}_{2(\text { ads })}^{-}+h^{+} \leftrightarrow \mathrm{NO}_{2(\text { gas })}
$$

The investigation of sensor properties of pure nanocrystalline oxides and hybrids in $\mathrm{NO}_{2}$ detection were performed with periodic illumination at room temperature. The concentration of $\mathrm{NO}_{2}$ was changed stepwise, first in the direction of increasing concentration, and then in descending order (Figure 9). With the growth of $\mathrm{NO}_{2}$ concentration, the resistance values of $R_{\text {light }}$ and $R_{\text {dark }}$ increased for all samples (Figure 9) in accordance with the dynamic equilibrium between the processes of $\mathrm{NO}_{2}$ adsorption (Equations (4) and (5)) and photodesorption (Equation (6)).
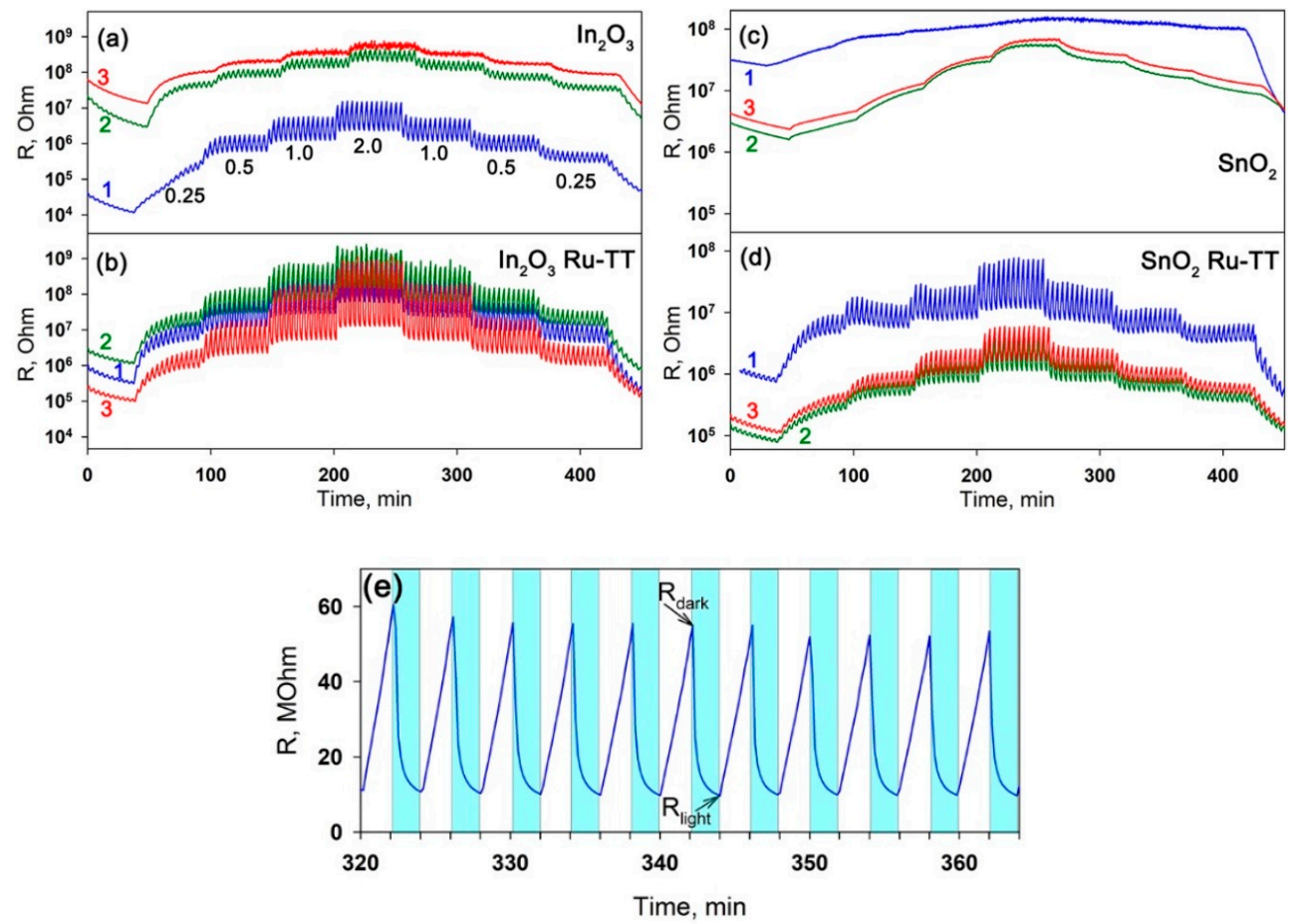

Figure 9. Room-temperature electrical resistances of (a) $\mathrm{In}_{2} \mathrm{O}_{3}$, (b) $\mathrm{In}_{2} \mathrm{O}_{3} \mathrm{Ru}-\mathrm{TT}$, (c) $\mathrm{SnO}_{2}$, and (d) $\mathrm{SnO}_{2}$ Ru-TT samples under periodic illumination, depending on $\mathrm{NO}_{2}$ content in the gas phase. (1): blue light $\left(\lambda_{\max }=470 \mathrm{~nm}\right),(2)$ : green light $\left(\lambda_{\max }=535 \mathrm{~nm}\right),(3)$ : red light $\left(\lambda_{\max }=630 \mathrm{~nm}\right)$. The digits on Figure $9 \mathrm{a}$ show the sequence of changes in $\mathrm{NO}_{2}$ concentration (ppm). (e) Room-temperature electrical resistance of the $\mathrm{In}_{2} \mathrm{O}_{3} \mathrm{Ru}$-TT sample in the presence of the 0.5-ppm $\mathrm{NO}_{2}$ concentration under periodic blue light $\left(\lambda_{\max }=470 \mathrm{~nm}\right)$ illumination. The shaded areas correspond to the "light on" period.

The amplitude of effective photoresponse (resistance change) at a fixed $\mathrm{NO}_{2}$ concentration is nearly constant (Figure 9e). Hence, the sensor signal can be calculated [35] as:

$$
S=\frac{R_{\text {dark }}}{R_{\text {dark } 0}}
$$


where $R_{\text {dark }}$ is the dark resistance (measured at the end of the 2-min "light off" period, Figure 7) at a given $\mathrm{NO}_{2}$ concentration and $R_{\text {dark } 0}$ is the dark resistance in pure air. This method of sensor signal calculation is preferred, since the adsorption of $\mathrm{NO}_{2}$ takes place to the greatest extent under the dark conditions.

Figure 10 compares the dependencies of the effective photoresponse and sensor signal on the concentration of $\mathrm{NO}_{2}$ in air for pure semiconductor oxides and hybrid materials under illumination with blue, green and red light.

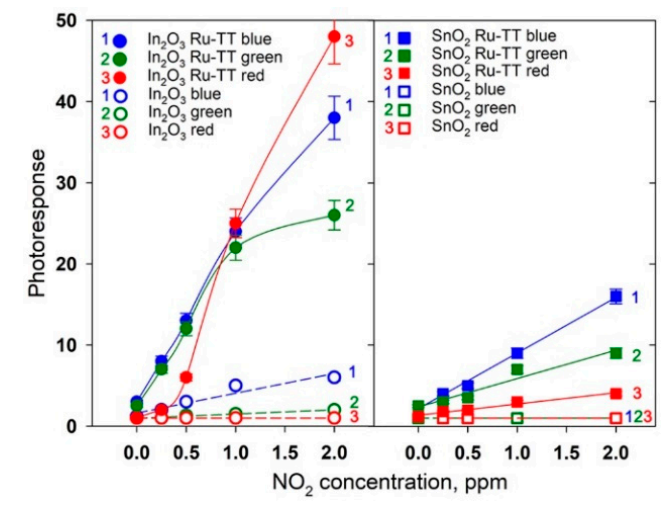

(a)

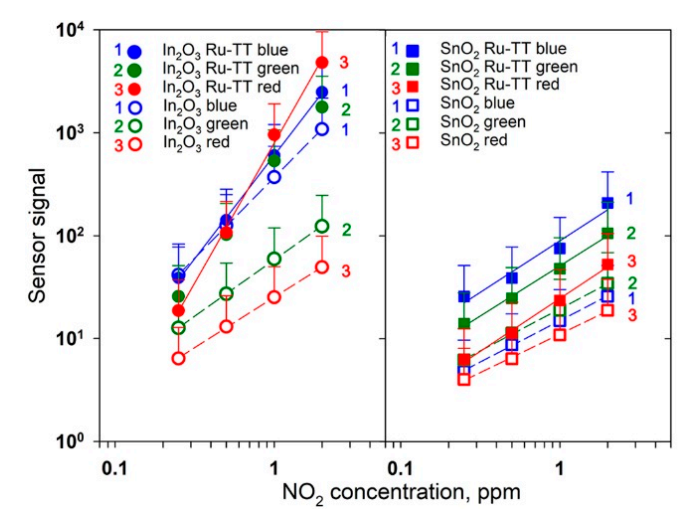

(b)

Figure 10. Effective room-temperature photoresponse (a) and sensor signal (b) of $\mathrm{In}_{2} \mathrm{O}_{3}$ - and $\mathrm{SnO}_{2}$-based samples under periodic visible light illumination, depending on $\mathrm{NO}_{2}$ content in the gas phase. Open symbols: data for blank matrixes, filed symbols: data for hybrid materials. (1): blue light $\left(\lambda_{\max }=470 \mathrm{~nm}\right),(2):$ green light $\left(\lambda_{\max }=535 \mathrm{~nm}\right),(3)$ : red light $\left(\lambda_{\max }=630 \mathrm{~nm}\right)$.

The main trends can be summarized as follows.

(i) Pure tin dioxide did not exhibit photosensitivity (Figure 9c), and the effective photoresponse $S_{P h}=1$ for all $\mathrm{NO}_{2}$ concentrations under illumination with blue, green and red light (Figure 10a). Nevertheless, the observed change in the resistance as a function of the $\mathrm{NO}_{2}$ concentration makes it possible to calculate the magnitude of the sensor signal by Equation (7). The maximum sensor signal of blank $\mathrm{SnO}_{2}$ was measured under green light illumination (Figure 10b). This effect can be due to the participation of oxygen vacancies of tin dioxide in the adsorption of $\mathrm{NO}_{2}$. As shown by the authors of [65], the acceptor levels related to the oxygen vacancies in $\mathrm{SnO}_{2}$ lie at $1.4 \mathrm{eV}$ (bridging vacancies) and $0.9 \mathrm{eV}$ (in-plane vacancies) above the valence band, which correspond to the energy of an electron transition from an acceptor level of $E_{a}=2.2 \mathrm{eV}(563 \mathrm{~nm})$ and $E_{a}=2.3 \mathrm{eV}(538 \mathrm{~nm})$, respectively. The absence of the photosensitivity $\left(S_{P h}=1\right)$, together with the measurable sensor signal $(S>1)$, can be due to the fact that, for the finely dispersed tin dioxide, the main process of interaction with $\mathrm{NO}_{2}$ is the reaction (5). Since the electron affinity of $\mathrm{NO}_{2}$ is larger than the one for $\mathrm{O}_{2}$, the position of energy levels of electrons localized on $\mathrm{NO}_{2}$ molecules chemisorbed on a $\mathrm{SnO}_{2}$ surface is deeper than that for chemisorbed oxygen. Thus, electron transfer in accordance with the reaction (5) will lead to a decrease in the Fermi level of the semiconductor. Since the band structure of nanocrystalline $\mathrm{SnO}_{2}$ with a particle size of 3-4 nm corresponds to the situation of flat zones [66], the decrease in the Fermi level indicates the decrease in the electrical conductivity, providing the sensor signal in the presence of $\mathrm{NO}_{2}$.

(ii) With a blue illumination, pure $\mathrm{In}_{2} \mathrm{O}_{3}$ exhibited a noticeable photosensitivity (Figure 9a). The value of the effective photoresponse at a fixed concentration of $\mathrm{NO}_{2}$ decreased with the increasing wavelength of the activating light (wavelengths of 470, 535 and $630 \mathrm{~nm}$ were used) (Figure 10a). A similar trend was observed for the concentration dependence of sensor signal. The maximum values of sensor signal in the whole range of $\mathrm{NO}_{2}$ concentrations were obtained under blue 
light (Figure 10b). This tendency is in accordance with the fact that for nanocrystalline $\operatorname{In}_{2} \mathrm{O}_{3}$, the photoconductivity is nonzero at photon energies more than $2.25 \mathrm{eV}(\lambda<550 \mathrm{~nm})$, which can be explained by the generation of electrons from localized levels located in the bandgap [64].

(iii) The sensitization of semiconducting oxides with the Ru-TT organic complex leads to the increase in both the effective photoresponse $S_{P h}$ of the materials and their sensor signal $S$ towards $\mathrm{NO}_{2}$ (Figure $9 \mathrm{~b}, \mathrm{~d}$ ). For the $\mathrm{SnO}_{2} \mathrm{R}$-TT hybrid material, the effective photoresponse and sensor signal values decreased upon transition from blue to green and then to red light illumination (Figure 10). The observed tendency agrees with the absorption spectrum and the spectral dependence of the photoconductivity of this hybrid material. In the case of the $\mathrm{In}_{2} \mathrm{O}_{3} \mathrm{Ru}$-TT hybrid, the maximum values of the photoresponse and the sensor signal at high concentrations of $\mathrm{NO}_{2}$ were obtained under red light. It appears to be an artifact. The values of the dark resistance $R_{\text {dark }}$ observed under these measurement conditions exceeded $10^{9} \mathrm{Ohm}$, which is the upper limit of the measuring system. The measurement of such resistances occurred with a large error and a high noise level.

\section{Materials and Methods}

\subsection{Materials Synthesis}

\subsubsection{Synthesis of $\mathrm{Ru}(\mathrm{II})$ Complex}

The synthesis of heteroleptic Ru(II) complex bis(2,2'-bipyridine- $\left.\mathrm{k}^{2} N^{1}, N^{1 \prime}\right)\left[2-\left(2,2^{\prime}\right.\right.$-bithiophen5-yl)- $1 H$-imidazo[4,5-f][1,10]phenanthroline- $\mathrm{k}^{2} N^{7}, N^{8}$ ) ruthenium $(2+)$ dichloride (Ru-TT) was carried out according to the scheme presented in Figure 11. The first stage was the oxidation of 1,10-phenanthroline with $\mathrm{KBrO}_{3}$ to provide phenetroline-6,10-dione [67]. Condensation reactions of the aldehydes with phenetroline-6,10-dione gave the ligand as a bright crystalline compound with good yield of 77\% [68,69]. To prepare the Ru-TT complex, an equimolar mixture of the ligand with $\mathrm{Ru}$ (bpy) $)_{2} \mathrm{Cl}_{2}$ (cis-bis(2,2-bipyridine)dichlororuthenium II hydrate) was kept in ethanol at $80{ }^{\circ} \mathrm{C}$ in sealed ampoule in argon for $8 \mathrm{~h}$ [70]. After complete reaction, the crude complex with a yield of $41 \%$ was purified by column chromatography.
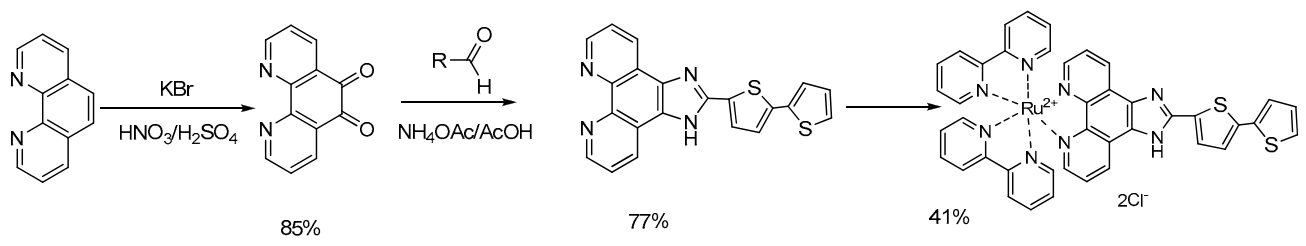

Figure 11. Scheme of the synthesis of Ru-TT complex.

The structure of the product was determined by ${ }^{1} \mathrm{H}$ NMR, ${ }^{13} \mathrm{C}$ NMR APT and MALDI-MS analysis.

${ }^{1} \mathrm{H}$ NMR (methanol-d4, $\delta$; ppm, J/Hz): $7.08\left(\mathrm{t}, 1 \mathrm{H},{ }^{3} \mathrm{~J}=4.3, \mathrm{Th}\left(4^{\prime}\right)\right), 7.22\left(\mathrm{~d}, 1 \mathrm{H},{ }^{3} \mathrm{~J}=3.8, \mathrm{Th}\left(3^{\prime}\right)\right)$, $7.26\left(\mathrm{~d}, 1 \mathrm{H},{ }^{3} \mathrm{~J}=3.5, \mathrm{Th}(3)\right), 7.37\left(\mathrm{~m}, 3 \mathrm{H}, \mathrm{Th}\left(5^{\prime}\right), \operatorname{Py}\left(5^{\prime}\right)\right), 7.57\left(\mathrm{t}, 2 \mathrm{H},{ }^{3} \mathrm{~J}=6.6, \operatorname{Py}(5)\right), 7.71\left(\mathrm{dd}, 2 \mathrm{H},{ }^{3} \mathrm{~J}=5.3\right.$, $\left.{ }^{3} J=8.2, \operatorname{ImPh}(5,10)\right), 7.74\left(\mathrm{~d}, 2 \mathrm{H},{ }^{3} J=5.7, \mathrm{Py}\left(6^{\prime}\right)\right), 7,81\left(\mathrm{~d}, 1 \mathrm{H},{ }^{3} \mathrm{~J}=3.7, \mathrm{Th}(4)\right), 7.97(\mathrm{~m}, 4 \mathrm{H}, \operatorname{ImPh}(6,9)$, $\operatorname{Py}(6)), 8.07\left(\mathrm{t}, 2 \mathrm{H},{ }^{3} \mathrm{~J}=7.9, \mathrm{Py}\left(4^{\prime}\right)\right), 8.18\left(\mathrm{t}, 2 \mathrm{H},{ }^{3} \mathrm{~J}=7.9, \mathrm{Py}(4)\right), 8.74\left(\mathrm{~d}, 2 \mathrm{H},{ }^{3} \mathrm{~J}=8.1, \mathrm{Py}\left(3^{\prime}\right)\right), 8.77(\mathrm{~d}, 2 \mathrm{H}$, $\left.{ }^{3} J=8.2, \operatorname{Py}(3)\right), 8.99\left(\mathrm{~d}, 2 \mathrm{H},{ }^{3} \mathrm{~J}=8.2, \operatorname{ImPh}(4,11)\right.$.

${ }^{13} \mathrm{C}$ NMR APT (methanol-d4, $\delta$; ppm, J/Hz): 123.93, 124.24, 124.35, 125.00, 125.13, 127.02, 127.53, $127.57,127.87,130.25,137.71,137.79,148.52,151.43,151.60$ [CH], 124.31, 134.30, 134.62, 136.37, 138.81, $150.93,144.94,157.20,157.42[C]$.

MALDI-MS m/z: $398[\mathrm{M}-2 \mathrm{Cl}]^{2+}$.

The chemical composition of the product $((\%) \mathrm{C}, 56.78 ; \mathrm{H}, 3.24 ; \mathrm{N}, 12.98 ; \mathrm{Ru}, 11.56)$ agrees well with the value calculated for $\mathrm{C}_{41} \mathrm{H}_{28} \mathrm{Cl}_{2} \mathrm{~N}_{8} \mathrm{RuS}_{2}((\%)$ : $\mathrm{C}, 56.68 ; \mathrm{H}, 3.25 ; \mathrm{N}, 12.90 ; \mathrm{Ru}, 11.63)$. 


\subsubsection{Synthesis of Nanocrystalline $\mathrm{SnO}_{2}$ and $\mathrm{In}_{2} \mathrm{O}_{3}$ and Hybrid Materials}

The powders of nanocrystalline $\mathrm{SnO}_{2}$ and $\mathrm{In}_{2} \mathrm{O}_{3}$ were prepared, from $\mathrm{SnCl}_{4} * 5 \mathrm{H}_{2} \mathrm{O}$ and $\mathrm{In}\left(\mathrm{NO}_{3}\right)_{3} \cdot 4.5 \mathrm{H}_{2} \mathrm{O}$, respectively, by chemical precipitation method as described in [28]. After the stages of washing and drying, the products were annealed in air at $300{ }^{\circ} \mathrm{C}$ for $24 \mathrm{~h}$.

To study the thermal stability and optical properties, hybrids based on the semiconductor oxides and Ru-TT complex were prepared in the form of powders. Firstly, Ru-TT was dissolved in methanol; then, $10 \mu \mathrm{L}$ of the obtained solution was added dropwise to the weighed sample of the semiconductor oxide and the paste was dried until the solvent was completely evaporated. The concentration of the solution was selected, so that the Ru content in the hybrids was $1 \mathrm{wt}$. \%.

To investigate the spectral dependence of photoconductivity and gas sensor properties, the hybrid materials were prepared in the form of thick films on alumina substrates with Pt electrodes on the top side and Pt microheater on the back side (Figure 12). The powders of $\mathrm{SnO}_{2}$ and $\mathrm{In}_{2} \mathrm{O}_{3}(\sim 10 \mathrm{mg})$ were mixed with a binder ( $\alpha$-terpineol in ethanol). The obtained pastes were deposited on the substrates by the micro dropping technique, dried at $30{ }^{\circ} \mathrm{C}$ for $24 \mathrm{~h}$ in air and sintered at $300{ }^{\circ} \mathrm{C}$ for $10 \mathrm{~h}$ in air using $\mathrm{Pt}$ microheaters. Then, the films were impregnated with the calculated amount of methanolic Ru-TT solution and dried at $50{ }^{\circ} \mathrm{C}$ for $24 \mathrm{~h}$. The estimated film thickness was about $2-3 \mu \mathrm{m}$.

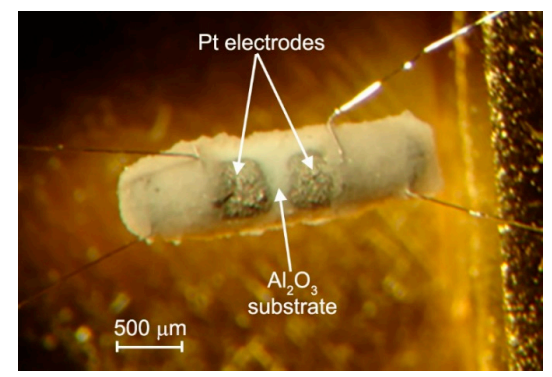

Figure 12. Optical image (top view) of the $\mathrm{Al}_{2} \mathrm{O}_{3}$ substrate with Pt electrodes. The Pt heather is on the back side (not shown).

\subsection{Materials Characterization}

The phase composition was examined by $\mathrm{X}$-ray powder diffraction (XRD) with D/MAX-2500V/PC diffractometer (Rigaku, Tokyo, Japan) $(\lambda=1.54059 \AA(\mathrm{Cu} \mathrm{K} \alpha 1$ radiation)). The crystallite sizes of $\mathrm{SnO}_{2}$ and $\mathrm{In}_{2} \mathrm{O}_{3}$ were calculated from the broadening of the most intensive XRD peaks using the Scherer equation. The single-point BET surface area of nanocrystalline oxides was determined using Chemisorb 2750 (Micromeritics, Norcross, GA, USA). The microstructure and composition of hybrid thick films were investigated directly on functional substrates (Figure 12) by scanning electron microscopy (SEM) combined with EDX at Zeiss NVision 40 (Carl Zeiss, Oberkochen, Germany) microscope equipped with an X-Max detector (Oxford Instruments, Abingdon, UK).

The thermal stability of hybrid materials was investigated by thermogravimetric analysis combined with mass spectroscopy analysis of gaseous products (TG-MS) using a thermal analyzer STA 409 PC Luxx (Netzsch-Gerätebau GmbH, Selb, Germany) with a quadrupole mass spectrometer QMS 403 C Aëolos (Netzsch-Gerätebau GmbH, Selb, Germany). The powders of hybrid materials were heated up to $500{ }^{\circ} \mathrm{C}$ with a heating rate of $10^{\circ} \mathrm{C} / \mathrm{min}$ in air.

The absorption spectrum of Ru-TT complex was measured with a Varian Cary 50 spectrometer (Varian Inc., Palo Alto, CA, USA) in the $200-800 \mathrm{~nm}$ range in $1 \mathrm{~nm}$ increments using a quartz cuvette with an optical path length of $10 \mathrm{~mm}$. The absorption spectra of semiconductor oxides and hybrid powders were obtained with a Perkin-Elmer Lambda-950 spectrometer (PerkinElmer Inc., Waltham, MA, USA) in the diffuse reflection mode in the $200-800 \mathrm{~nm}$ range in $1 \mathrm{~nm}$ increments with a preliminary subtraction of the baseline. 
The electrochemical characterization of the Ru-TT complex was carried out at $22{ }^{\circ} \mathrm{C}$ with an IPC-Pro M potentiostat (Volta, St. Petersburg, Russia). Cyclic voltammetry experiments were performed in a $1.0 \mathrm{~mL}$ cell equipped with a glassy carbon (GC) electrode (disk $d=2 \mathrm{~mm}$ ), $\mathrm{Ag} / \mathrm{AgCl} / \mathrm{KCl}$ (aq. saturated; reference electrode), and platinum electrode (counter electrode). The complexes were dissolved in degassed dry $\mathrm{CH}_{3} \mathrm{CN}$ containing tetra-(butyl)ammonium perchlorate (TBAP) as the supporting electrolyte $(0.10 \mathrm{M})$. Dry argon gas was bubbled through the solutions for $30 \mathrm{~min}$ before cyclic voltammetry experiments. The scan rate was $200 \mathrm{mVs}^{-1}$. A $10^{-3} \mathrm{M}$ solution of ferrocene with $0.1 \mathrm{M}$ TBAP in the same solvents was used for calibration.

The HOMO and LUMO energies of the Ru-TT complex were calculated using the methodology described in [71], using the following equations:

$$
\begin{aligned}
& E_{\mathrm{HOMO}}=-4.73-E_{\text {onset }(\mathrm{Ox})} \\
& E_{\mathrm{LUMO}}=-4.73-E_{\text {onset }}(\mathrm{Red})
\end{aligned}
$$

Spectral dependence of photoconductivity of hybrid materials was investigated in a cell shielded from the background light. Using a combination of the white light output of $100 \mathrm{~W} / \mathrm{cm}^{2}$ and an MDR-206 monochromator (LOMO Photonica, St. Petersburg, Russia), the samples were illuminated for $20 \mathrm{~s}$ at each wavelength with $5 \mathrm{~nm}$ increments. The dark interval between the measurements was $60 \mathrm{~min}$. The photoconductivity was calculated as a conductance ratio:

$$
\frac{\Delta \sigma}{\sigma_{0}}=\frac{\sigma(\lambda)-\sigma_{0}}{\sigma_{0}}
$$

where $\sigma(\lambda)$ is the film conductance under illumination with corresponding $\lambda, \sigma_{0}$ is the film conductance under dark conditions.

All sensor measurements were carried out at room temperature in the flow cell shielded from the background light under a controlled constant gas flux of $100 \mathrm{~mL} / \mathrm{min}$. DC measurements $(\mathrm{U}=3 \mathrm{~V})$ were carried out to monitor the electrical conductance of the sample during exposure to $\mathrm{NO}_{2}$ / air gas mixtures (0.25-2.0 ppm $\mathrm{NO}_{2}$ in dry air). Miniature light emission diodes (LEDs) with $\lambda_{\max }=470 \mathrm{~nm}$ (blue), $\lambda_{\max }=535 \mathrm{~nm}$ (green) and $\lambda_{\max }=630 \mathrm{~nm}$ (red) inserted into the cell were used as illumination sources.

\section{Conclusions}

It was demonstrated that the use of the heterocyclic $\mathrm{Ru}(\mathrm{II})$ complex (Ru-TT) as a photosensitizer results in a shift of the photosensitivity of the wide-gap nanocrystalline metal oxides $\mathrm{SnO}_{2}$ and $\mathrm{In}_{2} \mathrm{O}_{3}$ toward longer wavelengths. The creation of hybrid materials not only leads to an enhanced absorbance of nanocrystalline oxides in the visible range of the spectrum, but also expands the absorption region of the sensitized material, compared to the original organic dye. The shape of the spectral dependences of the hybrid's photoconductivity agrees with their optical absorption spectra. This indicates that the photoexcitation of organic dye is accompanied by the injection of electrons from the Ru-TT complex into $\mathrm{In}_{2} \mathrm{O}_{3}$ and $\mathrm{SnO}_{2}$ semiconductor matrixes. The sensitization of semiconducting oxides with the organic dye leads to the increase in both the effective photoresponse $S_{P h}$ of the materials and their sensor signal $S$ towards $\mathrm{NO}_{2}$. The ratios of the sensor signal to $2 \mathrm{ppm}$ of $\mathrm{NO}_{2}$ for sensitized and blank matrixes described for $\operatorname{In}_{2} \mathrm{O}_{3}$-based samples as $\frac{S_{I n 2 \mathrm{O} 3-R u T T}}{S_{I n 2 \mathrm{O} 3}}$, were $2.5,10$, and $10^{2}$ for the activating light wavelength at 470,535 and $630 \mathrm{~nm}$, respectively, and for the $\mathrm{SnO}_{2}$-based samples, written as $\frac{S_{S n O 2-R u T T}}{S_{S n O 2}}$, were approximately 8, 3, 3 under the illumination of the activating light at 470,535 and $630 \mathrm{~nm}$, respectively. Hybrid materials are capable to detect $\mathrm{NO}_{2}$ in the concentration range of $0.25-2$ ppm at room temperature (without the use of thermal heating) under periodic illumination with low-energy long-wavelength (red) light. From the point of view of increasing the sensor signal, the sensitization 
by the Ru-TT organic complex is more effective in cases where the semiconductor matrix is weakly sensitive to the radiation used.

Author Contributions: Conceptualization, M.R., O.F. and A.G.; data curation, A.N., S.T. and I.K.; formal analysis, A.N. and S.T.; investigation, A.N., S.V., S.T., O.F., I.K., K.D. and A.B.; methodology, M.R., S.V., O.F., K.D. and A.B.; supervision, M.R.; writing of the original draft, M.R., A.N. and O.F.; writing of review and editing, M.R., O.F. and A.G.

Funding: This research was funded by the Russian Ministry of Education and Sciences (Agreement No. 14.613.21.0075, RFMEFI61317X0075).

Acknowledgments: The TG-MS analysis and spectral research were carried out using the equipment purchased by funds of Lomonosov Moscow State University Program of the Development. The research by SEM and EDX was performed using the equipment of the Joint Research Center for Physical Methods of Research of Kurnakov Institute of General and Inorganic Chemistry of the Russian Academy of Sciences.

Conflicts of Interest: The authors declare no conflicts of interest.

\section{References}

1. World Health Organization. WHO Guidelines for Indoor Air Quality: Selected Pollutants, Geneva. 2010. Available online: http://www.euro.who.int/_data/assets/pdf_file/0009/128169/e94535.pdf (accessed on 12 August 2018).

2. Lian, K.-Y.; Hsiao, S.-J.; Sung, W.-T. Mobile Monitoring and Embedded Control System for Factory Environment. Sensors 2013, 13, 17379-17413. [CrossRef] [PubMed]

3. Krivetskiy, V.; Ponzoni, A.; Comini, E.; Badalyan, S.; Rumyantseva, M.; Gaskov, A. Selectivity Modification of $\mathrm{SnO}_{2}$-Based Materials for Gas Sensor Arrays. Electroanalysis 2010, 22, 2809-2816. [CrossRef]

4. Marikutsa, A.; Rumyantseva, M.; Baranchikov, A.; Gaskov, A. Nanocrystalline $\mathrm{BaSnO}_{3}$ as an alternative gas sensor material: Surface reactivity and high sensitivity to $\mathrm{SO}_{2}$. Materials 2015, 8, 6437-6454. [CrossRef] [PubMed]

5. Korotcenkov, G.; Brinzari, V.; Cho, B.K. $\mathrm{In}_{2} \mathrm{O}_{3}$ - and $\mathrm{SnO}_{2}$-Based Thin Film Ozone Sensors: Fundamentals. J. Sens. 2016, 2016, 3816094. [CrossRef]

6. Saura, J. Gas-sensing properties of $\mathrm{SnO}_{2}$ pyrolytic films subjected to ultraviolet radiation. Sens. Actuators $B$ 1994, 17, 211-214. [CrossRef]

7. Mishra, S.; Ghanshyam, C.; Ram, N.; Bajpai, R.P.; Bedi, R.K. Detection mechanism of metal oxide gas sensor under UV radiation. Sens. Actuators B 2004, 97, 387-390. [CrossRef]

8. Prades, J.D.; Diaz, R.J.; Hernandez-Ramirez, F.; Barth, S.; Cirera, A.; Romano-Rodriguez, A.; Mathur, S.; Morante, J.R. Equivalence between thermal and room temperature UV light modulated responses of gas sensors based on individual $\mathrm{SnO}_{2}$ nanowires. Sens. Actuators B 2009, 140, 337-341. [CrossRef]

9. Espid, E.; Taghipour, F. UV-LED Photo-activated Chemical Gas Sensors: A Review. Crit. Rev. Solid State Mater. Sci. 2017, 42, 416-432. [CrossRef]

10. Espid, E.; Taghipour, F. Development of highly sensitive $\mathrm{ZnO} / \mathrm{In}_{2} \mathrm{O}_{3}$ composite gas sensor activated by UV-LED. Sens. Actuators B 2017, 241, 828-839. [CrossRef]

11. Hsu, C.-L.; Chang, L.-F.; Hsueh, T.-J. Light-activated humidity and gas sensing by ZnO nanowires grown on LED at room temperature. Sens. Actuators B 2017, 249, 265-277. [CrossRef]

12. Ilin, A.; Martyshov, M.; Forsh, E.; Forsh, P.; Rumyantseva, M.; Abakumov, A.; Gaskov, A.; Kashkarov, P. UV effect on $\mathrm{NO}_{2}$ sensing properties of nanocrystalline $\mathrm{In}_{2} \mathrm{O}_{3}$. Sens. Actuators B 2016, 231, 491-496. [CrossRef]

13. Trawka, M.; Smulko, J.; Hasse, L.; Granqvist, C.-G.; Annanouch, F.E.; Ionescu, R. Fluctuation enhanced gas sensing with $\mathrm{WO}_{3}$-based nanoparticle gas sensors modulated by UV light at selected wavelengths. Sens. Actuators B 2016, 234, 453-461. [CrossRef]

14. Wongrat, E.; Chanlek, N.; Chueaiarrom, C.; Samransuksamer, B.; Hongsith, N.; Choopun, S. Low temperature ethanol response enhancement of $\mathrm{ZnO}$ nanostructures sensor decorated with gold nanoparticles exposed to UV illumination. Sens. Actuators A 2016, 251, 188-197. [CrossRef]

15. Saboor, F.H.; Ueda, T.; Kamada, K.; Hyodo, T.; Mortazavi, Y.; Khodadadi, A.A.; Shimizu, Y. Enhanced $\mathrm{NO}_{2}$ gas sensing performance of bare and $\mathrm{Pd}$-loaded $\mathrm{SnO}_{2}$ thick film sensors under UV-light irradiation at room temperature. Sens. Actuators B 2016, 223, 429-439. [CrossRef] 
16. Nakate, U.T.; Patil, P.; Bulakhe, R.N.; Lokhande, C.D.; Kale, S.N.; Naushad, M.; Mane, R.S. Sprayed zinc oxide films: Ultra-violet light-induced reversible surface wettability and platinum-sensitization-assisted improved liquefied petroleum gas response. J. Colloid Interface Sci. 2016, 480, 109-117. [CrossRef] [PubMed]

17. Klaus, D.; Klawinski, D.; Amrehn, S.; Tiemann, M.; Wagner, T. Light-activated resistive ozone sensing at room temperature utilizing nanoporous $\mathrm{In}_{2} \mathrm{O}_{3}$ particles: Influence of particle size. Sens. Actuators B 2015, 217, 181-185. [CrossRef]

18. Wagner, T.; Kohl, C.-D.; Malagù, C.; Donato, N.; Latino, M.; Neri, G.; Tiemann, M. UV light-enhanced $\mathrm{NO}_{2}$ sensing by mesoporous $\mathrm{In}_{2} \mathrm{O}_{3}$ : Interpretation of results by a new sensing model. Sens. Actuators B 2013, 187, 488-494. [CrossRef]

19. Cui, J.; Wang, D.; Xie, T.; Lin, Y. Study on photoelectric gas-sensing property and photogenerated carrier behavior of Ag-ZnO at the room temperature. Sens. Actuators B 2013, 186, 165-171. [CrossRef]

20. Wang, C.Y.; Becker, R.W.; Passow, T.; Pletsche, W.; Kohler, K.; Cimalla, V.; Ambacher, O. Photon-stimulated sensor based on indium oxide nanoparticles I: Wide-concedntration-range ozone monitoring in air. Sens. Actuators B 2011, 152, 235-240. [CrossRef]

21. Carotta, M.C.; Cervi, A.; Fioravanti, A.; Gherardi, S.; Giberti, A.; Vendemiati, B.; Vincenzi, D.; Sacerdoti, M. A novel ozone detection at room temperature through UV-LED-assisted ZnO thick film sensors. Thin Solid Films 2011, 520, 939-946. [CrossRef]

22. Peng, L.; Zhao, Q.; Wang, D.; Zhai, J.; Wang, P.; Pang, S.; Xie, T. Ultraviolet-assisted gas sensing: A potential formaldehyde detection approach at room temperature based on zinc oxide nanorods. Sens. Actuators $B$ 2009, 136, 80-85. [CrossRef]

23. Prades, J.D.; Jimenez-Diaz, P.; Manzanares, M.; Hernandez-Ramirez, F.; Cirera, A.; Romano-Rodriguez, V.; Mathur, S.; Morante, J.R. A model for the response towards oxidizing gases of photoactivated sensors based on individual $\mathrm{SnO}_{2}$ nanowires. Phys. Chem. Chem. Phys. 2009, 11, 10881-10889. [CrossRef] [PubMed]

24. Peng, L.; Xie, T.; Yang, M.; Wang, P.; Xu, D.; Pang, S.; Wang, D. Light induced enhancing gas sensitivity of copper-doped zinc oxide at room temperature. Sens. Actuators B 2008, 131, 660-664. [CrossRef]

25. De Lacy Costello, B.P.J.; Ewen, R.J.; Ratcliffe, N.M.; Richards, M. Highly sensitive room temperature sensors based on the UV-LED activation of zinc oxide nanoparticles. Sens. Actuators B 2008, 134, 945-952. [CrossRef]

26. Malagu, C.; Carotta, M.C.; Comini, E.; Faglia, G.; Giberti, A.; Guidi, V.; Maffeis, T.G.G.; Martinelli, G.; Sberveglieri, G.; Wilks, S.P. Photo-Induced Unpinning of Fermi Level in $\mathrm{WO}_{3}$. Sensors 2005, 5, 594-603. [CrossRef]

27. Zhang, C.; Geng, X.; Li, J.; Luo, Y.; Lu, P. Role of oxygen vacancy in tuning of optical, electrical and $\mathrm{NO}_{2}$ sensing properties of $\mathrm{ZnO}_{1-x}$ coatings at room temperature. Sens. Actuators B 2017, 248, 886-893. [CrossRef]

28. Chizhov, A.; Rumyantseva, M.; Vasiliev, R.; Filatova, D.; Drozdov, K.; Krylov, I.; Marchevsky, A.; Karakulina, O.; Abakumov, A.; Gaskov, A. Visible light activation of room temperature $\mathrm{NO}_{2}$ gas sensors based on $\mathrm{ZnO}, \mathrm{SnO}_{2}$ and $\mathrm{In}_{2} \mathrm{O}_{3}$ sensitized with CdSe quantum dots. Thin Solid Films 2016, 618, 253-262. [CrossRef]

29. Han, L.; Wang, D.; Lu, Y.; Jiang, T.; Chen, L.; Xie, T.; Lin, Y. Influence of annealing temperature on the photoelectric gas sensing of Fe-doped ZnO under visible light irradiation. Sens. Actuators B 2013, 177, 34-40. [CrossRef]

30. Geng, Q.; He, Z.; Chen, X.; Dai, W.; Wang, X. Gas sensing property of ZnO under visible light irradiation at room temperature. Sens. Actuators B 2013, 188, 293-297. [CrossRef]

31. Varechkina, E.N.; Rumyantseva, M.N.; Vasiliev, R.B.; Konstantinova, E.A.; Gaskov, A.M. UV-VIS photoconductivity of nanocrystalline tin oxide. J. Nanoelectron. Optoelectron. 2012, 7, 623-628. [CrossRef]

32. Han, L.; Wang, D.; Cui, J.; Chen, L.; Jiang, T.; Lin, Y. Study on formaldehyde gas-sensing of $\operatorname{In}_{2} \mathrm{O}_{3}$-sensitized ZnO nanoflowers under visible light irradiation at room temperature. J. Mater. Chem. 2012, 22, 12915-12920. [CrossRef]

33. Geng, X.; Zhang, C.; Debliquy, M. Cadmium sulfide activated zinc oxide coatings deposited by liquid plasma spray for room temperature nitrogen dioxide detection under visible light illumination. Ceram. Int. 2016, 42, 4845-4852. [CrossRef]

34. Geng, X.; You, J.; Zhang, C. Microstructure and sensing properties of CdS-ZnO ${ }_{1-x}$ coatings deposited by liquid plasma spray and treated with hydrogen peroxide solution for nitrogen dioxide detection at room temperature. J. Alloy. Compd. 2016, 68, 286-293. [CrossRef] 
35. Chizhov, A.S.; Rumyantseva, M.N.; Vasiliev, R.B.; Filatova, D.G.; Drozdov, K.A.; Krylov, I.V.; Abakumov, A.M.; Gaskov, A.M. Visible light activated room temperature gas sensors based on nanocrystalline $\mathrm{ZnO}$ sensitized with CdSe quantum dots. Sens. Actuators B 2014, 205, 305-312. [CrossRef]

36. Yang, Z.; Guo, L.; Zu, B.; Guo, Y.; Xu, T.; Dou, X. CdS/ZnO Core/Shell Nanowire-Built Films for Enhanced Photodetecting and Optoelectronic Gas-Sensing Applications. Adv. Opt. Mater. 2014, 2, 738-745. [CrossRef]

37. Vasiliev, R.; Babynina, A.; Maslova, O.; Rumyantseva, M.; Ryabova, L.; Dobrovolsky, A.; Drozdov, K.; Khokhlov, D.; Abakumov, A.; Gaskov, A. Photoconductivity of nanocrystalline $\mathrm{SnO}_{2}$ sensitized with colloidal CdSe quantum dots. J. Mater. Chem. 2013, 1, 1005-1010. [CrossRef]

38. Zhang, C.; Wang, J.; Olivier, M.-G.; Debliquy, M. Room temperature nitrogen dioxide sensors based on N719-dye sensitized amorphous zinc oxide sensors performed under visible-light illumination. Sens. Actuators B 2015, 209, 69-77. [CrossRef]

39. Peng, L.; Qin, P.; Zeng, Q.; Song, H.; Lei, M.; Mwangi, J.J.N.; Wang, D.; Xie, T. Improvement of formaldehyde sensitivity of $\mathrm{ZnO}$ nanorods by modifying with $\mathrm{Ru}(\mathrm{dcbpy})_{2}(\mathrm{NCS})_{2}$. Sens. Actuators B 2011, 160, $39-45$. [CrossRef]

40. Paolesse, R.; Nardis, S.; Monti, D.; Stefanelli, M.; Di Natale, C. Porphyrinoids for Chemical Sensor Applications. Chem. Rev. 2017, 117, 2517-2583. [CrossRef] [PubMed]

41. Kalyanasundaram, K.; Grätzel, M. Applications of functionalized transition metal complexes in photonic and optoelectronic devices. Coord. Chem. Rev. 1998, 177, 347-414. [CrossRef]

42. Roundhill, D.M.; Fackler, J.P., Jr. Photochemistry and Photophysics of Metal Complexes in Modern Inorganic Chemistry; Plenum Press: New York, NY, USA, 1994.

43. Kalyanasundaram, K. Photophysics, photochemistry and solar energy conversion with tris(bipyridyl)ruthenium(II) and its analogues. Coord. Chem. Rev. 1982, 46, 159-244. [CrossRef]

44. Bard, A.J.; Fox, M.A. Artificial Photosynthesis: Solar Splitting of Water to Hydrogen and Oxygen. Acc. Chem. Res. 1995, 28, 141-145. [CrossRef]

45. Sutin, N.; Creutz, C. Light induced electron transfer reactions of metal complexes. Pure Appl. Chem. 1980, 52, 2717-2738. [CrossRef]

46. Cook, M.J.; Lewis, A.P.; McAuliffe, G.S.G.; Skarda, V.; Thomson, A.J.; Glasper, J.L.; Robbins, D.J. Luminescent metal complexes. Part 2. A model for the luminescence properties of the tris-chelates of substituted 2,2'-bipyridyls with ruthenium (II). J. Chem. Soc. Perkin Trans. 2 1984, 8, 1303-1307. [CrossRef]

47. De Carvalho, I.M.M.; de Sousa Moreira, I.; Gehlen, M.H. Synthesis, Characterization, and Photophysical Studies of New Bichromophoric Ruthenium(II) Complexes. Inorg. Chem. 2003, 42, 1525-1531. [CrossRef] [PubMed]

48. Kitamura, N.; Kawanishi, Y.; Tazuke, S. Spectroscopic and electrochemical studies on ruthenium(II) complexes containing diazadiimine ligands. Chem. Phys. Lett. 1983, 97, 103-105. [CrossRef]

49. Rillema, D.P.; Allen, G.; Meyer, T.J.; Conrad, D. Redox properties of ruthenium(II) tris chelate complexes containing the ligands 2,2'-bipyrazine, 2,2'-bipyridine, and 2,2'-bipyrimidine. Inorg. Chem. 1983, 22, 1617-1622. [CrossRef]

50. Ross, H.B.; Boldaji, M.; Rillema, D.P.; Blanton, C.B.; White, R.P. Photosubstitution in tris chelate complexes of ruthenium(II) containing the ligands 2,2'-bipyrazine, 2,2'-bipyrimidine, 2,2'-bipyridine, and 4,4'-dimethyl-2,2'-bipyridine: Energy gap control. Inorg. Chem. 1989, 28, 1013-1021. [CrossRef]

51. Man'uel, D.J.; Strommen, D.P.; Bhuiyan, A.; Sykora, M.; Kincaid, J.R. Resonance Raman and Time-Resolved Resonance Raman Studies of Complexes of Divalent Ruthenium with Bipyridine and 4,4'-Bipyrimidine Ligands. J. Raman Spectrosc. 1998, 28, 933-938. [CrossRef]

52. Ernst, S.; Kaim, W. d ${ }^{6}$-Metal Complexes of 4,4'-Bipyrimidine, an Ambident Ligand with High $\pi$-Acceptor Ability. Angew. Chem. Int. Ed. Engl. 1985, 24, 430-431. [CrossRef]

53. Ernst, S.; Kaim, W.J. Energy level tailoring in ruthenium(II) polyazine complexes based on calculated and experimental ligand properties. Inorg. Chem. 1989, 28, 1520-1528. [CrossRef]

54. Jing, B.W.; Wu, T.; Tian, C.H.; Zhang, M.H.; Shen, T. pH-Dependent Luminescence of Ruthenium(II) Polypyridine Complexes. Bull. Chem. Soc. Jpn. 2000, 73, 1749-1755. [CrossRef]

55. Tan, L.F.; Wang, F.; Chao, H. Synthesis, DNA Binding, and DNA Photocleavage of the Ruthenium(II) Complexes $[\mathrm{Ru}(\mathrm{bpy})(\mathrm{btip})]^{2+}$ and $[\mathrm{Ru}(\mathrm{dmb})(\mathrm{btip})]^{2+} \quad\left(\right.$ bpy $=2,2^{\prime}$-Bipyridine; btip = 2-Benzo[b]thien-2-yl-1H-imidazo[4,5- $f][1,10]$ phenanthroline; dmb = 4,4'-Dimethyl-2,2' -bipyridine). Helv. Chim. Acta 2007, 90, 205-215. [CrossRef] 
56. Li, M.; Liu, J.; Sun, L.; Pan, J.; Zhao, C. Oligothiophene-2-yl-vinyl bridged mono- and binuclear ruthenium(II) tris-bipyridine complexes: Synthesis, photophysics, electrochemistry and electrogenerated chemiluminescence. J. Organomet. Chem. 2008, 693, 46-56. [CrossRef]

57. Sivalingam, Y.; Martinelli, E.; Catini, A.; Magna, G.; Pomarico, G.; Basoli, F.; Paolesse, R.; Di Natale, C. Gas-Sensitive Photoconductivity of Porphyrin-Functionalized ZnO Nanorods. J. Phys. Chem. 2012, 116, 9151-9157. [CrossRef]

58. Chizhov, A.S.; Mordvinova, N.E.; Rumyantseva, M.N.; Krylov, I.V.; Drozdov, K.A.; Li, X.; Gaskov, A.M. The effect of CdSe and InP quantum dots on the interaction of $\mathrm{ZnO}$ with $\mathrm{NO}_{2}$ under visible light irradiation. Russ. J. Inorg. Chem. 2018, 63, 512-518. [CrossRef]

59. Messias, F.; Vega, B.; Scalvi, L.; Li, M.; Santilli, C.; Pulcinelli, S. Electron scattering and effects of sources of light on photoconductivity of $\mathrm{SnO}_{2}$ coatings prepared by sol-gel. J. Non-Cryst. Solids 1999, 247, 171-175. [CrossRef]

60. Kornblit, L.; Ignatiev, A. Photodesorption threshold energies in semiconductors. Surf. Sci. Lett. 1984, 136, L57-L66. [CrossRef]

61. Ganose, A.M.; Scanlon, D.O. Band gap and work function tailoring of $\mathrm{SnO}_{2}$ for improved transparent conducting ability in photovoltaic. J. Mater. Chem. C 2016, 4, 1467-1475. [CrossRef]

62. Zhou, Z.; Gao, H.; Liu, R.; Du, B. Study of structure and property for the $\mathrm{NO}_{2}+\mathrm{NO}_{2}{ }^{-}$electron transfer system. J. Mol. Struct. THEOCHEM 2001, 545, 179-186. [CrossRef]

63. Šulka, M.; Pitoňák, M.; Neogrády, P.; Urban, M. Electron affinity of the $\mathrm{O}_{2}$ molecule: CCSD(T) calculations using the optimized virtual orbitals space approach. Int. J. Quantum Chem. 2008, 108, 2159-2171. [CrossRef]

64. Forsh, E.A.; Abakumov, A.M.; Zaytsev, V.B.; Konstantinova, E.A.; Forsh, P.A.; Rumyantseva, M.N.; Gaskov, A.M.; Kashkarov, P.K. Optical and photoelectrical properties of nanocrystalline indium oxide with small grains. Thin Solid Films 2015, 595, 25-31. [CrossRef]

65. Prades, D.; Arbiol, J.; Cirera, A.; Morante, J.R.; Avella, M.; Zanotti, L.; Comini, E.; Faglia, G.; Sberveglieri, G. Defect study of $\mathrm{SnO}_{2}$ nanostructures by cathodoluminescence analysis: Application to nanowires. Sens. Actuators B 2007, 126, 6-12. [CrossRef]

66. Bârsan, N.; Weimar, U. Conduction Model of Metal Oxide Gas Sensors. J. Electroceram. 2001, 7, $143-167$. [CrossRef]

67. Shuzhang, X.; Tao, Y.; Yifeng, Z.; Zhao, Q.; Fuyou, L.; Chunhui, H. Multi-state molecular switches based on dithienylperfluorocyclopentene and imidazo[4,5-f] [1,10]phenanthroline. Tetrahedron 2006, 62, 10072-10078. [CrossRef]

68. Batista, R.M.F.; Costa, S.P.G.; Belsley, M.; Lodeiro, C.; Raposo, M.M.M. Synthesis and characterization of novel (oligo)thienyl-imidazo-phenanthrolines as versatile p-conjugated systems for several optical applications. Tetrahedron 2008, 64, 9230-9238. [CrossRef]

69. Cai, Z.; Zhou, M.; Xu, J. Degenerate four-wave mixing determination of third-order optical nonlinear of three mixed ligand nickel (II) complexes. J. Mol. Struct. 2011, 1006, 282-287. [CrossRef]

70. Li, Z.; Yang, H.; Zhang, A.; Luo, H.; Wang, K. pH effects on optical and DNA binding properties of a thiophene-containing ruthenium(II) complex. Inorg. Chim. Acta 2011, 370, 132-140. [CrossRef]

71. Rumyantseva, M.; Makeeva, E.; Gaskov, A.; Shepel, N.; Peregudova, S.; Khoroshutin, A.; Tokarev, S.; Fedorova, $\mathrm{O} . \mathrm{H}_{2} \mathrm{~S}$ sensing by hybrids based on nanocrystalline $\mathrm{SnO}_{2}$ functionalized with $\mathrm{Cu}$ (II) organometallic complexes: The role of the ligand platform. Nanomaterials 2017, 7, 384. [CrossRef] [PubMed]

(C) 2018 by the authors. Licensee MDPI, Basel, Switzerland. This article is an open access article distributed under the terms and conditions of the Creative Commons Attribution (CC BY) license (http://creativecommons.org/licenses/by/4.0/). 